\title{
A Closer Look at Cardioprotective Function of HDL: Revise the HDL - Cholesterol Hypothesis?
}

\author{
Anna Meiliana ${ }^{1,2, *}$, Andi Wijaya ${ }^{1,2}$ \\ ${ }^{1}$ Postgraduate Program in Clinical Biochemistry, Hasanuddin University, Jl. Perintis Kemerdekaan Km.10, Makassar, Indonesia \\ ${ }^{2}$ Prodia Clinical Laboratory, Jl. Cisangkuy No.2, Bandung, Indonesia \\ *Corresponding author. E-mail: anna.meiliana@prodia.co.id
}

\section{Abstract}

$\mathrm{B}$ ACKGROUND: The strong inverse association of plasma levels of high-density lipoprotein (HDL) cholesterol with coronary heart disease (CHD) found in human epidemiological studies led to the development of the 'HDL cholesterol hypothesis', which posits that intervention to raise HDL cholesterol will result in reduced risk of CHD. A number of recent developments have brought the potential protective role of HDL into question. Several clinical trials of agents that substantially raise HDL-C have been demonstrated to not reduce CHD event rates.

CONTENT: For decades, HDL and HDL-cholesterol (HDL-C) levels were viewed as synonymous, and modulation of HDL-C levels by drug therapy held great promise for the prevention and treatment of cardiovascular disease. Nevertheless, recent failures of drugs that raise HDL-C to reduce cardiovascular risk and the now greater understanding of the complexity of HDL composition and biology have prompted researchers in the field to redefine HDL. As such, the focus of HDL has now started to shift away from a cholesterol-centric view toward HDL particle number, subclasses, and other alternative metrics of HDL. Many of the recently discovered functions of HDL are, in fact, not strictly conferred by its ability to promote cholesterol flux but by the other molecules it transports, including a diverse set of proteins, small RNAs, hormones, carotenoids, vitamins, and bioactive lipids. Based on HDL's ability to interact with almost all cells and deliver fatsoluble cargo, HDL has the remarkable capacity to affect a wide variety of endocrine-like systems.

SUMMARY: There is a significant need to redefine HDL and its benefit. HDL transports a diverse set of functional

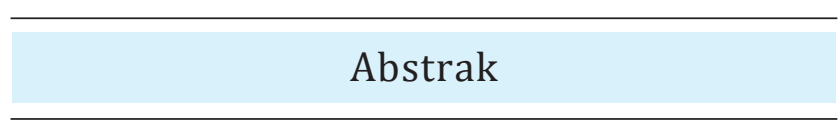

ᄃ

ATAR BELAKANG: Penelitian epidemik pada manusia menunjukkan hubungan terbalik yang kuat antara kolesterol high-density lipoprotein (HDL) plasma dengan penyakit jantung coroner (PJK). Hal ini memicu perkembangan "hipotesis kolesterol HDL" yang menyatakan bahwa peningkatan kadar HDL dapat mengurangi risiko PJK. Banyak perkembangan saat ini yang mempertanyakan potensi proteksi HDL. Beberapa uji klinis menunjukkan bahwa peningkatan kolesterol HDL secara substansial ternyata tidak mengurangi laju kejadian PJK.

ISI: Selama beberapa dekade, kadar HDL dan kolesterol HDL dianggap sama, dan terapi obat yang dapat meningkatkan kadar kolesterol HDL diharapkan dapat digunakan untuk mencegah dan mengobati penyakit kardiovaskular. Namun, kegagalan obat peningkat kadar kolesterol HDL dalam mengurangi risiko kardiovaskular, ditambah dengan pemahaman yang lebih baik mengenai kompleksitas komposisi dan biologi HDL, menuntut para peneliti untuk mendefinisikan ulang HDL. Dengan demikian, fokus HDL saat ini bergeser dari kolesterol menuju ke jumlah partikel HDL, subklas dan metriks HDL lainnya. Beberapa penemuan akhir-akhir ini menunjukkan fakta bahwa fungsi HDL sesungguhnya bukan meningkatkan keluaran kolesterol melainkan melalui molekul lain yang dibawa, HDL membawa bermacam protein yang berlainan, small RNA, hormon, karotenoid, vitamin, dan lemak bioaktif. Berdasarkan kemampuan HDL untuk berinteraksi dengan hampir semua sel dan mengantarkan muatan larut lemak, HDL memiliki kapasitas luar biasa untuk mempengaruhi sebagian besar sistim dalam tubuh yang menyerupai endokrin.

RINGKASAN: Perlu definisi ulang mengenai HDL dan 
proteins, including many binding proteins. HDL transports and deliver vitamins, carotenoids, and other small molecules. Moreover, HDL transports hormones, steroids and bile acids, and can modulate multiple endocrine pathways. HDLs also transport and deliver microRNAs to recipient cells and control gene expression. Likewise, HDLs carry bioactive lipids and can activate signaling cascades and receptors that control endothelial apoptosis, migration, survival and activation. Many of HDL's alternative noncholesterol cargo likely confer many of HDL's alternative functions.

KEYWORDS: HDL, ApoA1, RCT, ABCA1, ABCG1, miRNA, HDL Lipidome, HDL Proteome

Indones Biomed J. 2014; 6(1): 17-32 fungsinya. HDL mentransportasikan berbagai macam protein fungsional, meliputi beberapa protein pengikat. HDL membawa dan mengantar vitamin, karotenoid, dan molekul kecil lainnya. Lebih dari itu, HDL juga mengantar hormon, steroid dan asam empedu, dan dapat mengatur berbagai jalur endokrin. HDL juga mengantar microRNA ke sel penerima dan mengendalikan ekspresi gen. HDL mengangkut lemak bioaktif dan dapat mengaktifkan kaskade sinyal dan reseptor yang mengendalikan apoptosis, migrasi, pertahanan hidup dan aktivasi endotel. Beberapa muatan non kolesterol yang dibawa HDL tampaknya juga menambah fungsi alternatif HDL.

KATA KUNCI: HDL, ApoA1, RCT, ABCA1, ABCG1, miRNA, HDL Lipidome, HDL Proteome

\section{Introduction}

In population studies, high-density lipoprotein cholesterol (HDL-C) is inversely related to the risk of myocardial infarction and death.(1-4) Of note, in patients fully treated according to current guidelines with intense statin therapy and low-density lipoprotein cholesterol (LDL-C) at target levels, HDL-C remains predictive of outcome for major adverse cardiovascular events.(5) HDL and HDL-C levels are often considered to be one and the same, referred to as "good" cholesterol, mainly due to the epidemiologically observed inverse association of HDL-C to cardiovascular disease (CVD) risk. As a consequence, billions of dollars and herculean effort were invested into HDL biology and pharmacological strategies to raise HDL-C levels for the prevention and treatment of CVD.(6) However, interventions that increase the concentration of HDL-C in humans have not yet been shown to translate into a reduction in clinical cardiovascular events. Indeed, recent human clinical trials investigating the effects of raising the level of HDL-C by treatment with cholesteryl ester transfer protein (CETP) inhibitors or with niacin failed to demonstrate any clinical cardiovascular benefit.(7-9)

A reasonable assumption that has been made from these studies is that the cholesterol content of HDLs is not the factor that protects. Thus, while the concentration of HDL-C is generally an excellent marker of the HDL functions that do protect, it does not invariably reflect their cardioprotective functions.(10) Thus, the pathogenic role and, hence, suitability of HDL as a therapeutic target has increasingly been questioned. In fact, it has been argued that low HDL-C may only represent a marker for proatherogenic risk factors, rather than HDL being a mediator protecting against atherogenesis.(11) Such a conclusion neglects the structural and functional heterogeneity of HDL, which is neither reflected by the nonfunctional clinical biomarker HDL-C nor has yet been targeted by randomized controlled trials $(7,9,12,13)$ or Mendelian randomization studies $(14,15)$.

Several well-documented functions of HDL and apolipoprotein AI (ApoA-I) report the potential to protect against CVD. The most extensively studied was the ability of HDLs to promote efflux of cholesterol from macrophages in the artery wall.(16) HDL inhibits vascular inflammation $(17,18)$, and has antioxidant (17) and antithrombotic (19) properties. HDL also enhances endothelial function (20), promotes endothelial repair $(21,22)$, increases angiogenesis (23), suppresses the production and mobilization of monocytes and neutrophils from bone marrow (24), and have recently been reported to have antidiabetic property $(25,26)$. Which of these HDL functions are clinically important is not known. Nor is it known which HDL component(s) or subpopulations are responsible for these potentially cardioprotective properties. Until we know which HDL components and subpopulations relate to specific potentially cardioprotective functions and until we have much more information about the effects of HDL-raising therapies on HDL composition, HDL subpopulation distribution, and HDL function, it will be difficult to predict how any specific HDL-targeted therapy will impact on human cardiovascular risk.(10) 
What has become apparent in the course of these sobering messages regarding HDL-C is that cholesterolbased measures of HDL may only tell us part of the story. HDL is known to circulate in plasma as a heterogeneous cohort of particles, varying markedly in terms of size, shape, and composition of proteins and lipids. To what degree this influences the relative functional properties of these particles and their ability to protect the artery wall remains unknown. (27) Given that interventions that increase the concentration of HDL-C may not necessarily be accompanied by an enhancement of HDL function, it is clear that we need to understand much more about how HDL function relates to HDL subpopulation distribution and cardiovascular risk in order to develop rational HDL-based therapeutic strategies for preventing atherosclerosis. (10)

\section{HDL Metabolism and Heterogeneity}

HDLs are typically defined as lipoprotein particles with buoyant densities from 1.063 to $1.21 \mathrm{~g} / \mathrm{mL}$ and having

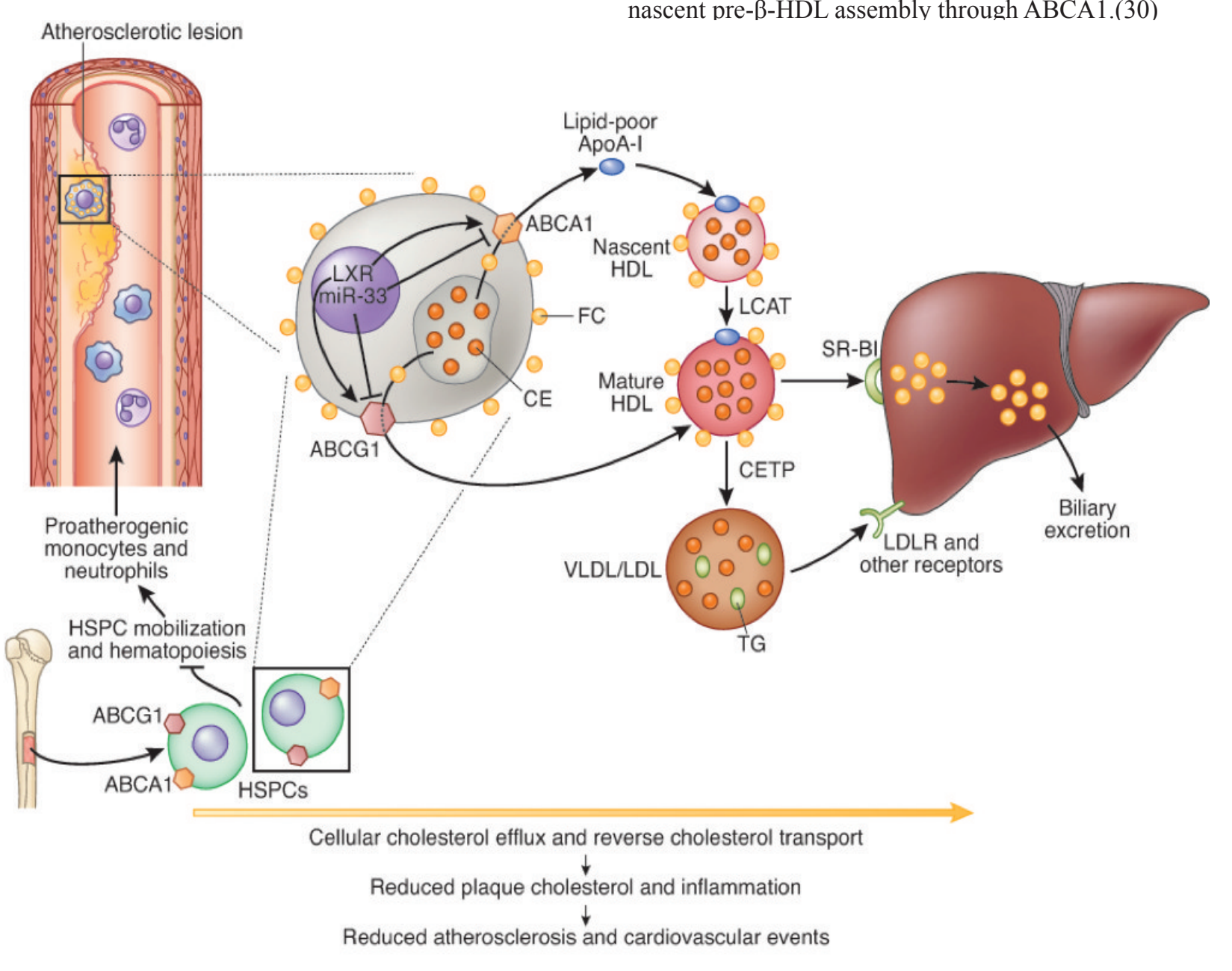

ApoA-I as the major apolipoprotein species. It has become increasingly appreciated that the HDL population consists of a collection of particles with diverse sizes, structures, and composition and functional properties that are thought to influence atheroprotectiveness. The compositional complexity reflects not only multiple species of proteins and lipids but also other macromolecules (e.g., microRNA (miRNA)).(28)

Reverse cholesterol transport is generally used to describe the transport of cholesterol by HDL from the vascular wall to the liver for excretion into bile as neutral sterol or bile acid.(29) de novo synthesis of HDL involves the secretion of ApoA-I by liver and small intestine into circulation, followed by a largely extracellular acquisition of phospholipids (PL) and cholesterol leading to the formation of nascent HDL. The early ApoA-I lipidation with free cholesterol (FC) and phosphatidylcholine (PC) occurs on its critical interaction with ATP-binding cassette sub-family A member 1 (ABCA1) and results in the formation of discoidal pre- $\beta$-HDL particles. ApoM is an HDL-associated apolipoprotein that affects HDL biogenesis by affecting nascent pre- $\beta$-HDL assembly through ABCA1.(30)

Figure 1. Pathways influencing HDL cholesterol metabolism and flux and potential relationship to atherosclerosis.(31) (Adapted with permission from Nature Publishing Group). 
In the circulation, nascent disc-shaped HDL is, under normal conditions, thought to mature into larger spherical HDL. This process entails acquisition of cholesteryl ester (CE) in its hydrophilic lipid core, a step made possible through lecithin cholesterol acyltransferase (LCAT). In the circulation, several proteins and enzymes modulate HDL. In humans, these include CETP, PL transfer protein (PLTP), hepatic lipase (LIPC), endothelial lipase (LIPG), and secreted phospholipase A2 (sPLA2).(32) CETP accommodates the transfer of CE from HDL to ApoBcontaining lipoproteins in exchange for triglycerides (TG). PLTP is crucial to HDL particle remodeling. PLTP facilitates the transfer of PL from TG-rich lipoprotein (TRL) to HDL with the formation of both larger and smaller particles, whereas it can also induce fusion of smaller HDL. $(33,34)$ LIPC is involved in breaking-down HDL-TG and PL, thereby reducing HDL size and enhancing the dissociation of lipid-free/lipid-poor ApoA-I from larger HDL.(35) LIPG, a second lypolytic enzyme, is expressed in the liver, lung, kidney, and placenta. The enzyme has shown to exhibit more phospholipase activity than TG lipase activity with a major preference for HDL instead of TRL. sPLA2 is highly expressed in the liver, particularly during acute and chronic inflammatory states. This enzyme hydrolyzes the sn- 2 ester bond of PL to release a lyso PL and a nonesterified free fatty acid.(36)

Proteins and enzymes that affect HDL metabolism through their impact on plasma TG lipolysis. These mostly affect the activity of lipoprotein lipase (LPL), the sole enzyme capable of hydrolyzing plasma TG in plasma TRL. LPL is synthesized and secreted by parenchymal cells in metabolically active muscle and adipose tissue. At these sites, surface lipid (FC and PL) and apolipoproteins resulting from TRL hydrolysis are conveyed from TRL to HDL.(35,37) For its catalytic activity, LPL needs apoC-II as cofactor, a small protein of 79 amino acids present on TRLs and HDL. ApoA-V can be considered as a modulator of LPL activity. ApoA-V (11q23) is expressed in the liver and the protein is secreted into plasma, where it associates with very low-density lipoprotein (VLDL), chylomicrons, and HDL. It seems to be a key modulator of plasma TG homeostasis but the molecular mechanisms are not fully understood. $(38,39)$ The LPL reaction is regulated in a spatiotemporal fashion by several inhibitory factors encoded by ApoC-III, angiopoietin-like 3 (ANGPTL3), and ANGPTL4, which all affect HDL metabolism. It has been suggested that ApoCIII increases the catabolism of HDL and is involved in other relevant lipid metabolic functions.(40) Both encoded proteins can act as inhibitors of LPL activity by promoting, in different ways, the dissociation of the active LPL

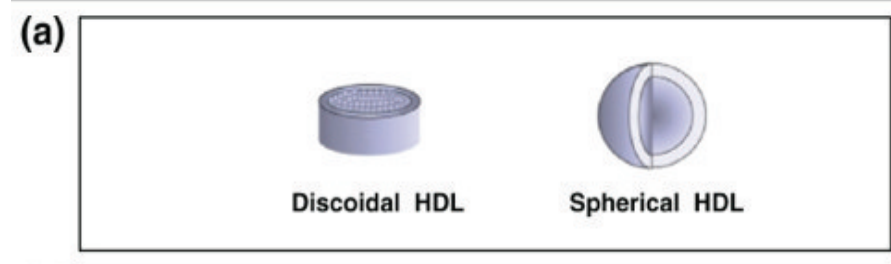

(b)

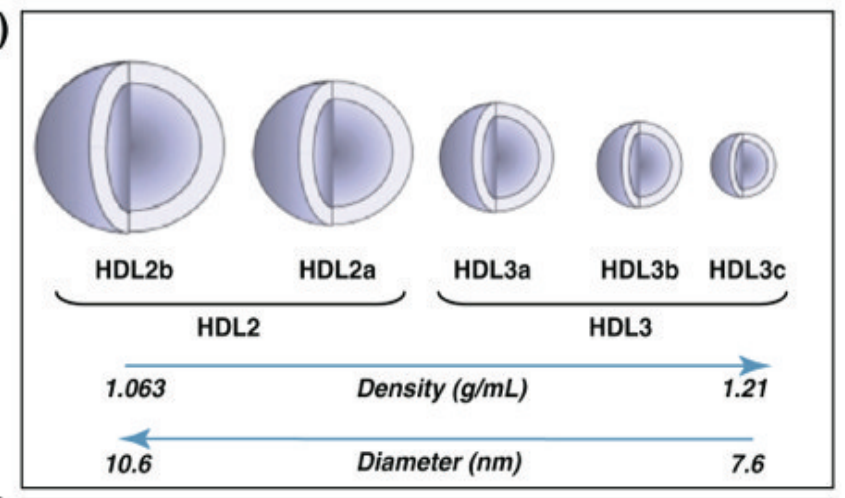

(c)

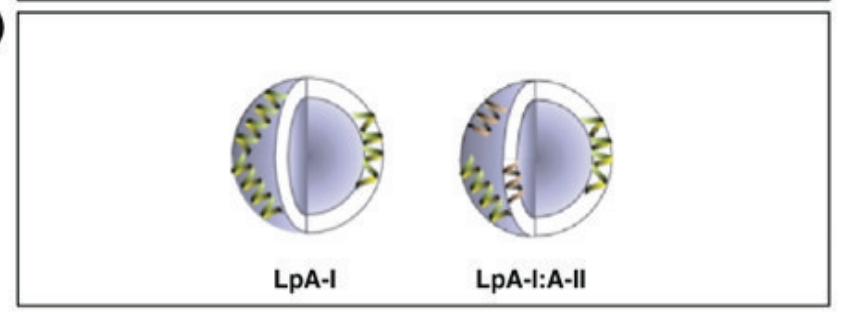

(d)

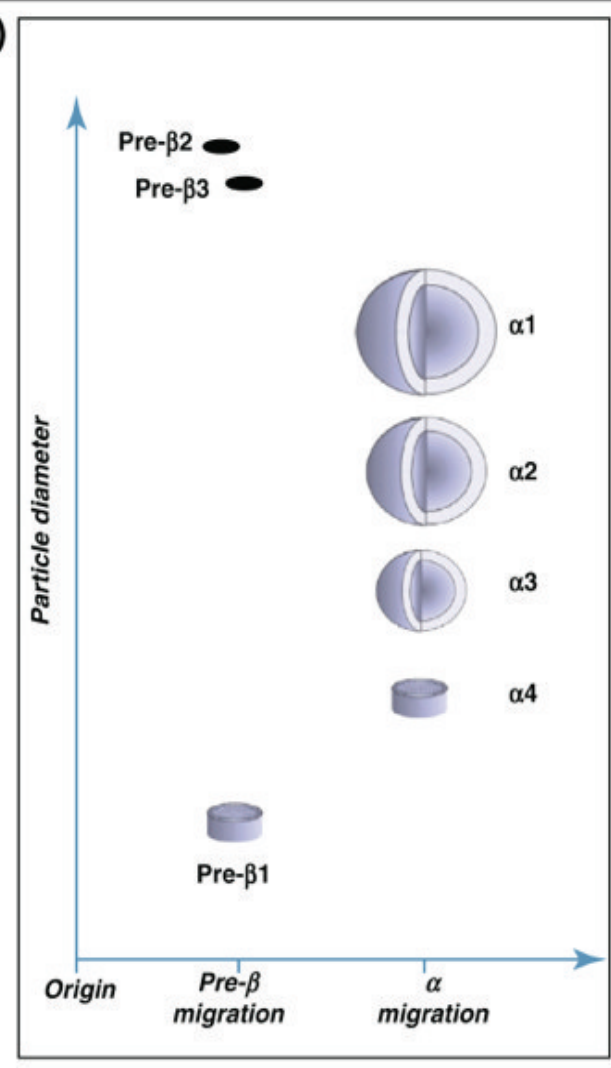

TRENDS in Molecular Medicine

Figure 2. Heterogeneity of HDL particles. (42) (Adapted with permission from Elsevier Ltd.). 
homodimer into inactive monomers. Scavenger receptor class B type I (SR-BI), as the main high-affinity receptor for HDL, enables the selective uptake of CE from circulating HDL via ApoA-I recognition. This occurs, however, without mediating the degradation of HDL, as is the case for LDL.(41) Plasma HDL particles are, however, highly heterogeneous in structure, composition and biological function.

Such heterogeneity results from differences in the relative content of apolipoproteins and lipids in HDL.(42) A topic of considerable clinical and biological interest is whether specific subfractions of HDL are more informative in assessing the benefits of a therapeutic intervention targeted to HDL.

\section{HDL Metabolome, Lipidome and Proteome}

HDL's ability to participate in the reverse cholesterol transport (RCT) pathway is, likely an important part of its anti-atherogenic role. We are now beginning to realize the full breadth of HDL's function and cargo; thus, there is a significant need to begin to rethink and possibly focus on these other aspects of HDL besides its role in transporting cholesterol. Although it is not clear what the new focus on HDL should be, we review here the latest findings related to the metabolome, transcriptome, lipidome, and proteome of HDL.

Besides lipids, we know relatively little about the repertoire of small molecules circulating on HDL; however, this will likely be an emerging new field for HDL research. As HDL is possibly rebranded as a general transporter of cargo between cells, a comprehensive characterization of HDL's metabolome is warranted. Some of the best studied small metabolites carried by HDL are the fat-soluble vitamins.(43-46) A majority of $\alpha$-tocopherol (vitamin E), for example, is transported in plasma by lipoproteins, including HDL, and delivered to recipient cells by way of lipoproteins. Most interestingly, HDL delivery of vitamin E to epithelial cells was found to be independent of SR-BI, as chemical inhibition of with basic lipid transport-1 (BLT-1) failed to reduce vitamin E delivery.(47) Conversely, endothelial cell uptake of HDL-vitamin E was found to be mediated by SRBI. $(43,48)$ Vitamin $\mathrm{E}$ is an essential antioxidant vitamin, although the relevance of HDL-mediated vitamin E transfer between cells is currently unknown.

Unlike vitamin $\mathrm{E}$, most of vitamin $\mathrm{D}$ is believed to be bound to a specific serum-binding protein. The vitamin D-binding protein, however, is routinely found in proteomic studies to be associated with HDL. $(49,50)$ Most interestingly, vitamin D and vitamin D receptor modulators have been found to inhibit ApoA-I.(51,52)

Retinol (vitamin A) is also likely transported in various forms on HDL. Similar to vitamin D, retinol associates with a binding protein, the plasma retinol-binding protein (PRBP), which has also been reported in multiple studies to be associated with HDL.(50) HDL also transports many carotenoids, which are lipophilic precursors for vitamin A. (46) Although HDL only transports a small percentage (of total plasma mass) of nonpolar carotenoids (e.g., lycopene, $17 \%$; $\alpha$-carotene, $26 \%$; and $\beta$-carotene, $22 \%$ ), a large percentage of polar carotenoids are found on HDL (lutein, $53 \%$; cryptoxanthin, $39 \%)$.(53)

One of the most widely studied carotenoid, $\beta$-carotene, has been found to inhibit atherosclerosis in hypercholesterolemic rabbits and is associated with HDL. (54) HDL has also been found to transport ubiquinone (UQ) (coenzyme Q or coenzyme Q10) and may facilitate the intercellular transfer of UQ or dietary intake delivery of UQ to recipient cells.(55) Although the role of UQ in disease is not fully understood, HDL-mediated transport of UQ has been proposed to possibly help prevent heart failure, cancer, migraines, and hypertension.

Currently, the functional relevance of the intercellular transfer of the HDL metabolome is not fully understood, nor have we likely identified all the small molecules that can be transported by HDL. A comprehensive analysis of the HDL metabolome is warranted and will likely uncover other metabolites and homeostatic networks affected by HDL.

The lipids carried by HDL can be largely categorized as being either neutral hydrophobic lipids (CE and TG), which are carried in the core of HDL, or amphipathic lipids, such as cholesterol or PL, which are on the surface of HDL. (6)

It is not cholesterol, however, but PL that quantitatively predominate in the HDL lipidome, accounting, together with sphingomyelin (SM), for 40-60 $\mathrm{wt} \%$ of total lipid, with lesser proportions of CE (30-40\%), TG (5-12\%), and FC (5-10\%). Structurally, individual HDL lipid classes fulfill distinct functions; PL constitute the surface lipid monolayer of HDL, whereas CE and TG form the hydrophobic lipid core. Unesterified sterols are predominantly located to the surface monolayer, partially penetrating the core.(56)

Recently, it has been realized that some of the lipids carried by HDL can be transformed into potent bioactive molecules. For example, PC, the most common PL on HDL, is highly susceptible to oxidation, which after hydrolysis generates the highly reactive and damaging lyso-PC (LPC). $(57,58)$ 
SM, another common class of lipids on HDL, is a substrate for neutral sphingomyelinase-2 (nSMase2) in the ceramide signaling pathway.(59) SM can also be converted to lysosphingolipids, namely, sphingosylphosphorylcholine and lysosulfatide, which have been found to protect against endothelial apoptosis through activation of Akt signaling. Most interestingly, the Akt-signaling cascade is responsible for HDL-lipid suppression of apoptosis, as inhibition of Akt phosphorylation of $\mathrm{BCl}$-2-associated death (BAD) promoter blocked the HDL-lipid effect.(60) Recent evidence suggests that the lysosphingolipid sphingosine-1-phosphate (S1P) may mediate many actions of HDL such as vasodilation, angiogenesis and endothelial barrier function, and protection against atherosclerosis and ischemia/reperfusion injury. $(61,62)$

High HDL levels do not always protect against CVD and there is accumulating evidence suggesting that simply increasing the circulating HDL-C does not necessarily confer cardiovascular benefits. $(8,63)$ This leads to the hypothesis that the HDL in some patients may be dysfunctional and its other properties and compositions like S1P might be more important than its cholesterol cargo. (65) Evidence suggests that HDL serves as an S1P signaling platform and likely mediates a multitude of cardiovascular effects, and therapeutic strategies involving HDL S1P hold much promise for the future. Recent applications of mass spectrometry technology have dramatically increased our understanding of the proteomic diversity of HDL. Depending on the method of HDL isolation, upwards of 85 proteins have been identified, and the list continues to grow. (66)

HDL carries surprising constituents, such as members of the complement pathway, protease inhibitors involved in hemostasis, acute-phase response proteins, immune function mediators, and even metal-binding proteins. This compositional diversity fits well with hundreds of studies demonstrating a wide functional pleiotrophy, including roles in lipid transport, oxidation, inflammation, hemostasis, and immunity. The recent studies of the HDL proteome have revealed that besides the "classic" proteins on HDL, such as ApoA-I, that largely serve a structural role in HDL or a role in its metabolism, HDL cargo includes other proteins that may have distinct biological effects and could account for some of the other functions of HDL besides cholesterol transport . Recently, we discovered that HDL also transports small RNAs, including miRNA, tRNA-derived RNA fragments (tRF), and RNase P-derived RNA fragments. (67) Outside of cholesterol efflux, HDL has many other beneficial functions, and unique miRNA, lipid, protein, and small molecule components likely mediate each, if not all of these functions, including cytoprotective, anti-thrombotic, anti-infectious, vasodilatory, and many other functions to be discovered.

\section{Biological Activities of HDL Subpopulations}

HDL possesses several antiatherogenic activities which involve cholesterol efflux from cells as well as antioxidative, anti-inflammatory, cytoprotective, vasodilatory, anti-thrombotic and anti-infectious activities. $(68,69)$ The efflux of cholesterol from a variety of cell types, including macrophages, to HDLs in the extracellular space is mediated by four distinct processes.(70). These are: i) the efflux of cholesterol to ApoA-I from cells expressing ABCA1 $(71,72)$; ii) the efflux of cholesterol to HDLs from cells expressing ABCG1 $(73,74)$; iii) the bidirectional exchange of cholesterol between HDLs and cell membranes expressing sSR-B1 (75,76); and iv) passive aqueous diffusion of cholesterol from cell membranes to HDLs (75).

Several miRNAs, for example, miR33, miR122, and miR144, decrease the production of ABCA1 and hence reduce cholesterol efflux.(77-79) Thus, cholesterol

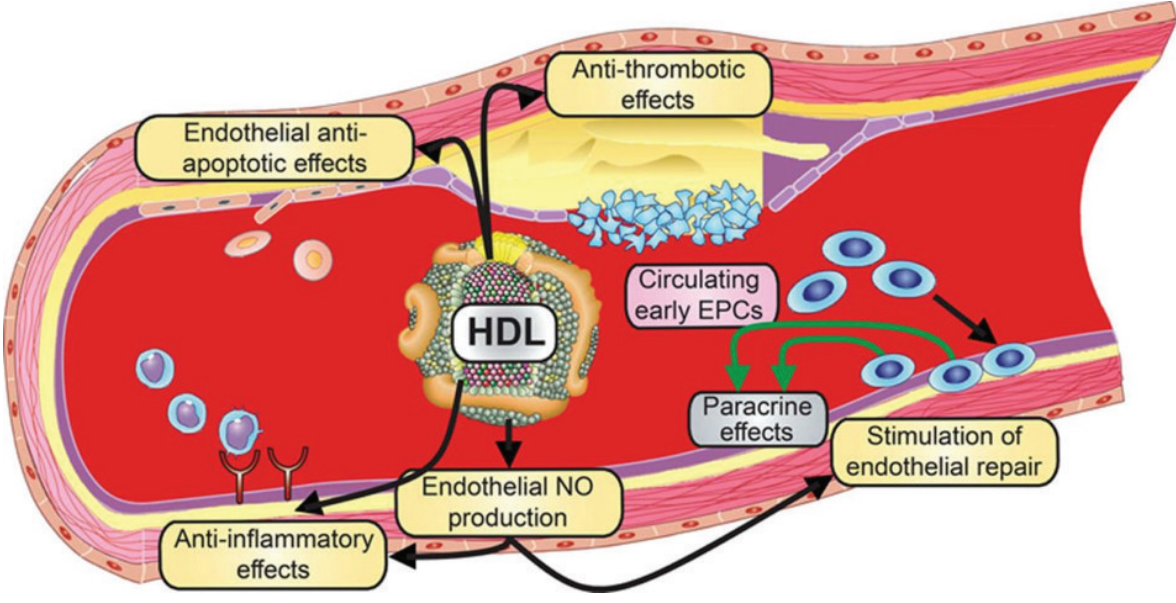

Figure 3. Proposed direct vascular protective and potentially antiatherogenic effects of normal HDL.(5) (Adapted with permission from American Heart Association). 
efflux is determined by the extracellular concentration and composition of HDL particles as well as by the activity of ABC transporters. By finetuning cellular cholesterol homeostasis, cholesterol efflux by ApoA-I / ABCA1- and HDL-mediated efflux in concert with ABCG1 exerts important regulatory steps on many cellular functions, including proliferation and mobilization of hematopoietic stem cells (79). ABCG4-mediated cholesterol efflux to HDL regulates megakaryocyte proliferation.(80) Cholesterol efflux also regulates the inflammatory responses of monocytes and macrophages (81), expansion of lymphocytes (82), nitric oxide (NO) production by endothelial NO synthase (eNOS) (83), and insulin secretion from pancreatic $\beta$-cells (84).

When comparing cholesterol efflux properties of HDL subpopulations, it is essential to keep in mind the concentration basis employed for such comparison. Thus, on the basis of PL content, small, dense HDLs more potently promote cholesterol efflux, whereas on a particle number basis, large HDLs are more effective. $(85,86)$

HDLs possess antioxidant properties that have the capacity to inhibit the proatherogenic oxidative modification of LDL.(87) The mechanism by which HDLs inhibit oxidation is uncertain. The most extensively studied aspect of this process involves activity of paraoxonase-1 (PON-1), which is transported in the plasma as a component of the HDL fraction.(88) ApoA-I (89), ApoA-II (89), ApoA-IV $(90,91)$ and ApoE (92) all have antioxidant properties in vitro. Which of these apolipoproteins, if any, is also antioxidant in vivo is not known. HDL particles are also heterogeneous in their capacity to protect LDL from oxidative damage induced by one-electron oxidants such as free radicals. A non-uniform distribution of apolipoproteins, enzymes and lipids across the HDL particle spectrum could underlie this observation. There is evidence that the antioxidant activity of HDL 3 is superior to that of HDL 2.(42) It has also been reported that PL modulate the antioxidant properties of HDLs.(93)

Inflammation plays a pivotal role in both the genesis and the instability of atherosclerotic plaques. HDLs have the capacity to inhibit this inflammation by multiple mechanisms. They inhibit the binding of monocytes to cultured endothelial cells in vitro.(87) They also reduce the cytokine induced expression of vascular cell adhesion molecule-1 (VCAM-1), intercellular adhesion molecule-1 (ICAM-1), and E-selectin in cultured endothelial cells in a concentration dependent manner.(18) The ability of HDLs to inhibit inflammation in endothelial cells in vitro varies according to the PL composition of the particles (94), with their constituent apolipoproteins exhibiting much lower specificity (95).
Protein that is induced both in vitro (96) and in vivo (97) by rHDLs is the antioxidant protein $3 \beta$-hydroxysteroid- $\Delta 24$ reductase (also known as 24-dehydrocholesterol reductase or DHCR24). Silencing DHCR24 expression in endothelial cells not only increases nuclear factor $\mathrm{\kappa B}(\mathrm{NF}-\mathrm{\kappa B})$ activation and VCAM-1 protein levels in both nonactivated and TNF$\alpha$-activated endothelial cells, but it is also associated with a loss of the anti-inflammatory effects of rHDLs.(96)

The potential heterogeneity of HDL anti-inflammatory activity remains poorly characterised. Small, dense, proteinrich HDL3 has been reported to be superior to large, light, lipid-rich HDL2 in terms of capacity to inhibit VCAM1 expression in endothelial cells on the basis of both ApoA-I and total cholesterol (98), consistent with the potent antioxidative activity of small, dense HDL3 (99). HDL from healthy subjects can exert several protective effects in the vasculature and, in particular, on endothelial cells. Of note, HDL from healthy subjects stimulates NO release from human aortic endothelial cells in culture and increases the expression of eNOS.(100-103) HDLs display cytoprotective activity, an effect attributed to ApoA-I, ApoE and HDL-associated lysosphingolipids and observed as a prevention of endothelial cell apoptosis elicited by growth factor withdrawal and other agents.(104) This antiatherogenic activity is paralleled by the ability of HDL to stimulate endothelial cell migration and survival, an effect potentially mediated by S1P.(105) HDLs inhibit thrombosis by attenuating expression of tissue factor and selectins, by downregulating thrombin generation via the protein $\mathrm{C}$ pathway, and by directly and indirectly blunting platelet activation.(19) Inhibition of platelet activation is also dependent on SR-B1.(106,107) HDLs enhance endothelial repair by two distinct mechanisms. They stimulate endothelial cell migration from healthy to damaged endothelium via the SR-B1-mediated activation of Rac GTPase in a process involving activation of Src kinases, phosphatidyl inositol 3 kinase (PI3K), and p44/42 mitogen-activated protein kinases.(21) In addition, HDLs can promote endothelial repair in vivo by enhancing the engraftment of endothelial progenitor cells into areas of damaged endothelium.(22)

Studies conducted in mice have shown that suppression of the cholesterol efflux promoted by ABCA1 and ABCG1 in bone marrow cells leads to hematopoietic stem cell proliferation and mobilization.(24) Importantly, HDL particles can progressively lose normal biological activities and acquire altered properties as a result of alterations in HDL composition, structure and metabolism, which are characteristic of dyslipidemia, insulin resistance, inflammation, infection and CVD.(68) 


\section{HDL Endothelial Dysfunction and Atherosclerosis}

HDL has the potential to protect against atherosclerosis by multiple mechanisms, including the removal of cholesterol from macrophages in the arterial wall in the first step of the reverse cholesterol transport pathway.(108) HDL also inhibit vascular inflammation and oxidation, enhance endothelial repair, and improve endothelial function. $(97,109)$ Endothelial injury and dysfunction (ED) represent a link between cardiovascular risk factors promoting hypertension and atherosclerosis, the leading cause of death in western populations. HDL is considered anti-atherogenic and known to prevent ED.(110)

HDL-C has direct effects on numerous cell types that influence cardiovascular and metabolic health. These include endothelial cells, vascular smooth-muscle cells, leukocytes, platelets, adipocytes, skeletal muscle myocytes, and pancreatic $\beta$ cells. The effects of HDL or ApoA-I, its major apolipoprotein, occur through the modulation of intracellular calcium, oxygen-derived free-radical production, numerous kinases, and enzymes, including eNOS. ApoA-I and HDL also influence gene expression, particularly genes encoding mediators of inflammation in vascular cells. In many paradigms, the change in intracellular signaling occurs as a result of cholesterol efflux, with the cholesterol acceptor methyl $-\beta$-cyclodextrin often invoking responses identical to HDL or ApoA-I. The ABCA1, ABCG1 and SRBI frequently participate in the cellular responses.(111)

HDL has been suggested to protect endothelial cell functions by prevention of oxidation of LDL and its adverse endothelial effects. Moreover, HDL from healthy subjects can directly stimulate endothelial cell production of NO and anti-inflammatory, anti-apoptotic, and anti-thrombotic effects as well as endothelial repair processes $(101,112$ 114). Hessler, Robertson, and Chisolm (115) reported early on that HDL protects against LDL-induced cytotoxicity on endothelial cells. HDL was demonstrated to prevent copperinduced LDL oxidation or LDL oxidation by cultured endothelial cells.(116-118) HDL is a major carrier of lipid peroxidation products (119-120) which are thought to play a role in the initiation and progression of atherosclerotic vascular disease.(121) HDL can directly inhibit oxidation of LDL via transfer of oxidation products from LDL to HDL.(119) A study by Navab et al.(122) demonstrated that ApoA-I binds to and removes lipid hydroperoxides of LDL in vitro and in vivo.

ApoE has been shown to have allele-specific antioxidant activity.(123) ApoE-II can stimulate endothelial
NO release and has anti-inflammatory activities.(124) In contrast, ApoE-IV has been described as pro-inflammatory. (125) It has also been reported that HDL-associated Apo-J can inhibit LDL oxidation by artery wall cells.(126) In addition, ApoA-IV has been demonstrated to exert antioxidant, anti-inflammatory, and anti-atherosclerotic actions in vivo. $(91,127,128)$

Notably, HDL also carries antioxidant enzymes that may be involved in prevention of lipid oxidation or degradation of lipid hydroperoxides such as PON1, LCAT, and platelet-activating factor acetylhydrolase (PAF-AH). In particular, PON1 has been suggested to be an important regulator of the potential anti-atherogenic capacity of HDL. $(129,130)$ endothelial NO (eNO) plays a crucial role in the regulation of vascular tone and structure. eNOS-derived NO has been shown to exert a variety of atheroprotective effects in the vasculature, such as anti-inflammatory and anti-thrombotic effects.(131) Reduced eNO bioavailability has therefore been suggested to promote initiation and progression of atherosclerosis (131). Accumulating evidence suggests that HDL can directly stimulate eNOSmediated NO production via endothelial SR-BI.(101)

HDL binding to SR-BI initiates tyrosine kinase Srcmediated activation of PI3K, which in turn activates Akt and MAPK/extracellular signal-regulated kinase (Erk) pathway.(132) Activation of endothelial Akt by HDL stimulates phosphorylation of eNOS at serine residue 1177 $(112,132)$, which is known to be an important regulatory mechanism leading to eNOS activation.(133) HDL is thought to contribute to atheroprotection as an antiinflammatory through, for example, antioxidant properties of its enzymatic and non-enzymatic components, the ability to remove normal and toxic lipid species from cells, and the dampening of Toll-like receptor (TLR) signaling by regulating plasma membrane cholesterol content.(134136) The anti-inflammatory effects of HDL included changes in the balance between M1 and M2 macrophages. (28) How HDL contributes to a reduction in M1 or an enhancement in M2 polarization may depend on a number of its properties. As noted, there is growing evidence that it or ApoA-I may limit TLR responsiveness to inflammatory stimuli (by regulating plasma membrane cholesterol content and microenvironments), and there is more recent evidence indicating that it can promote the phosphorylation of STAT6, an integral signaling component of the M2 polarization pathway.(135-140) Furthermore HDL reduced eNO availability via TLR-2 leading to impaired endothelial repair, and increased proinflammatory activation. These data demonstrate how symmetric dimethylarginine (SDMA) can modify the HDL particle to mimic a damage-associated 
molecular pattern that activates TLR-2 via TLR-1- or TLR6-coreceptor-independent pathway, linking abnormal HDL to innate immunity, ED, and hypertension.(110)

In pathological studies of coronary atherosclerotic plaque erosion, thrombi were observed in direct contact with the intima in areas with absent endothelium likely promoting disease progression.(141) Endothelial cell apoptosis has therefore been suggested to contribute importantly to the pathophysiology of coronary disease. (142-144) The capacity of HDL to attenuate endothelial cell apoptosis may therefore represent a potentially important anti-atherogenic property of HDL.(60,145-147)

\section{Inflammation Alters HDL Composition and Function}

Recent studies provided convincing evidence that inflammation generates dysfunctional or even proatherogenic forms of HDL by promoting PL depletion and enrichment with pro-inflammatory proteins such as serum amyloid A (SAA), ApoC-III or complement component 3 (C3).(148-151) HDL loses potential anti-atherosclerotic properties in patients with chronic inflammatory disorders such as the anti-PL syndrome (152), systemic lupus erythematosus and rheumatoid arthritis (153), scleroderma (154), the metabolic syndrome (155), diabetes $(156,157)$, and coronary disease $(100,158,159)$. Notably, in a study of
189 patients with chronic kidney disease on hemodialysis, an impaired anti-inflamatory capacity of HDL was correlated with a poor clinical outcome.(160)

HDL from coronary artery disease (CAD) subjects is dysfunctional. In fact, HDL from many CAD patients was actually proinflammatory, thus increasing monocyte chemotaxis in response to LDL, unlike the HDL from healthy controls that reduced monocyte chemotaxis. There are many possible alterations between this dysfunctional HDL and normal functional HDL.(161) These pro-inflammatory HDL particles have been termed "dysfunctional" HDL. The heterogeneity of the vascular effects of HDL may be attributed to changes in the HDL-associated proteome and lipids, i.e., post-translational protein modifications and changes in the amount and type of proteins and lipids bound to the HDL particle. In particular, HDL is susceptible to oxidation / modification in vitro by a variety of oxidants, such as metal ions, peroxyl and hydroxyl radicals, aldehydes, various myeloperoxidase (MPO)-generated oxidants, lipoxygenase, phospholipase A2, elastase, nonenzymatic glycation, and homocysteinylation.(162)

Inflammation induces major changes in HDL levels and composition. Mediators of inflammation such as tumor necrosis factor (TNF)- $\alpha$ and interleukin (IL)-6 induce expression of serum amyloid A (163) and sPLA2-IIA (164), which dramatically alter HDL apolipoprotein content and levels, respectively. Acute phase SAA in the plasma is associated with HDL, where it can comprise the major

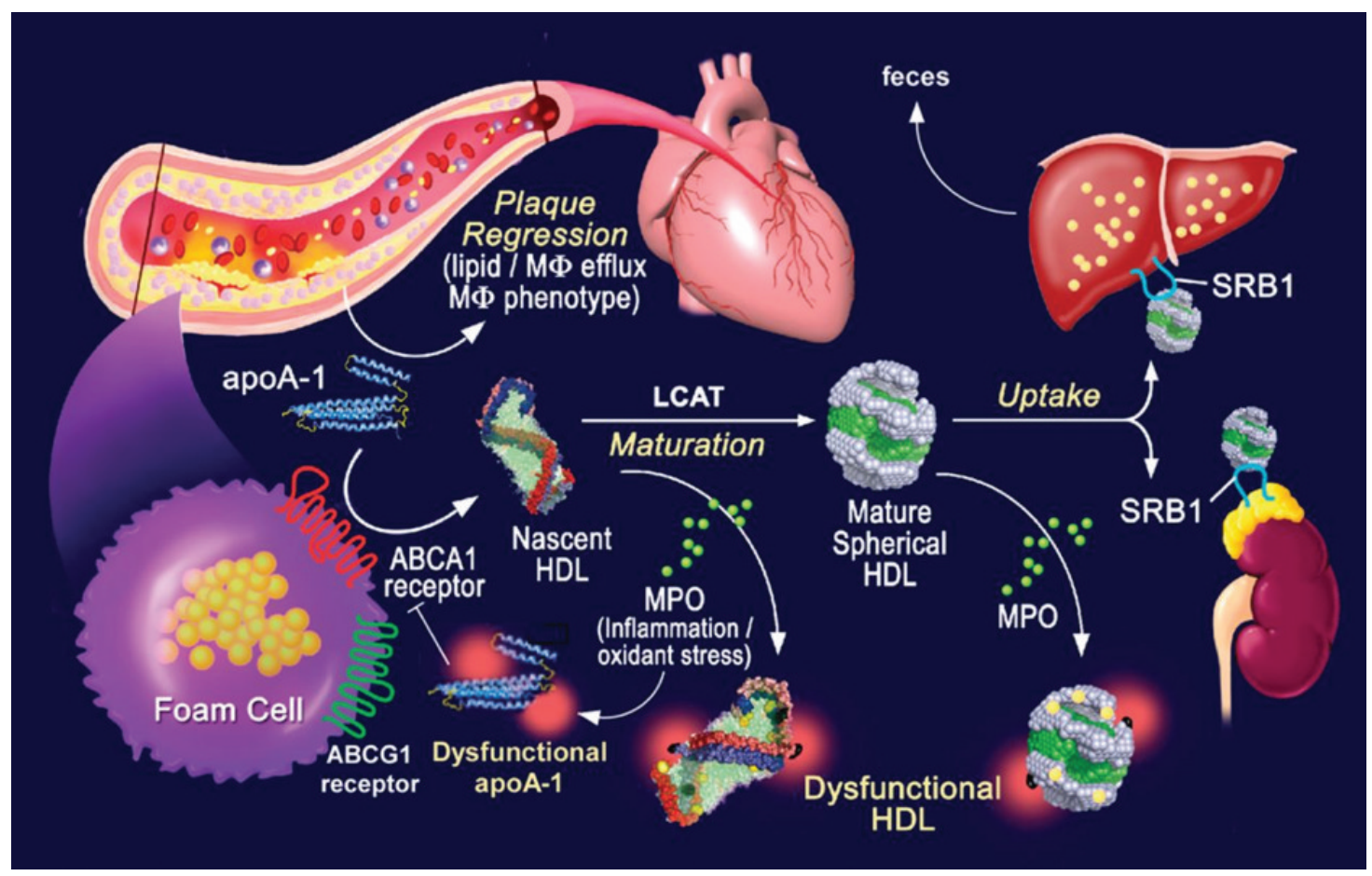

Figure 4. HDL dysfunction impairs reverse cholesterol transport.(171) (Adapted with permission from American Heart Association). 
apolipoprotein.(165) The increase in sPLA2-IIA activity results in hydrolysis of HDL surface PL and a decrease in HDL particle size.(166) The presence of SAA on HDL holds the potential to impact both the CE transfer and the ApoA-I liberating ability of CETP. sPLA2-IIA could also impact the latter action of CETP as ApoA-I was shown to dissociate more readily from CETP-remodeled reconstituted HDL after hydrolysis by bee venom phospholipase A2.(167)

Post-translational modification of ApoA-I can directly lead to HDL dysfunction. HDL from diabetic subjects can have glycated ApoA-I with altered lipid-binding activity, and incubation of HDL with glucose impaired its antiinflammatory and antioxidant activities. $(168,169)$

One of the best studied modifications of ApoA-I is mediated by MPO, a leukocyte-derived heme protein abundant in neutrophils, monocytes, and a subset of tissue macrophages. Part of the innate immune host defense system, MPO uses $\mathrm{H}_{2} \mathrm{O}_{2}$ to generate an array of reactive oxidant and free radical species that are antimicrobial, such as hypochlorous acid $(\mathrm{HOCl})$. These same species can also foster spurious oxidative injury to normal tissues as well, such as within atherosclerotic plaque, where MPO has been shown to promote both protein modifications and initiate lipid peroxidation. Once released from activated leukocytes, in the circulation and within lesions, MPO has been shown to bind to HDL. This tight binding, which has been mapped to helix 8 region of ApoA-I, likely accounts for the selective oxidative targeting of ApoA-I within HDL for modification by MPO-generated oxidants.(170) These and other recent observations support a role for MPO serving as an enzymatic catalyst for site-specific modification of ApoA-I and HDL, leading to functional impairment within the artery wall. Indeed, HDL isolated from human atherosclerotic plaque has been shown to coimmunoprecipitate with MPO.(171)

Subsequent studies have revealed that MPO-induced modification of ApoA-I/HDL inhibits additional HDL functions. For example, oxidative modification of ApoA-I Tyr166 through MPO-catalyzed nitrating and chlorinating pathways is linked to functional impairment of HDL binding to LCAT activation and activity.(172) Similarly, oxidation of ApoA-I Met148 also impairs LCAT activation (173). HDL exposure to MPO or $\mathrm{HOCl}$ results in the loss of anti-apototic and anti-inflammatory activities of HDL, and specifically the loss of SR-B1-binding activity, while increasing its proinflammatory activities, such as endothelial cell NF-KB activation and VCAM-1 expression.(156)

Taken together, plasma HDL-C levels are likely not an appropriate marker of vascular effects of HDLs, and therefore do not represent a reliable therapeutic target. Inflammation is proposed to impair HDL function and RCT.
This may be of pathophysiological significance because attenuation of RCT might contribute to atherosclerosis in chronic inflammatory states, including metabolic syndrome and type 2 Diabetes Mellitus.(161)

Tests for HDL function or biomarkers associated with dysfunctional HDL may be useful for identifying subjects at risk for CAD. For example, plasma MPO levels are positively associated with $\mathrm{CAD}$ and the risk of a subsequent major adverse cardiac event. $(174,175)$ Similarly, the level of ApoA-I chlorotyrosine, detected by mass spectrometry, is also a predictor of CVD. Although this assay may be for a potential means of quantifying dysfunctional HDL levels, it is not suitable for routine clinical use.(170)

\section{Novel Therapies Focused on HDL Particle}

The hypothesis that HDL-C directly confers biological protection against atherosclerosis has, as of yet, never been proved and, as a consequence, HDL-C has been argued to be merely a CVD biomarker rather than an active player in atherogenesis. This notion has gained support because therapies with an established HDL-C increasing effect were shown not to result in the anticipated decrease in CVD risk. In particular, 3 large outcome trials were prematurely terminated for futility (Athero-thrombosis Intervention in Metabolic Syndrome with Low HDL/High TG: Impact on Global Health Out-comes [AIM-HIGH] trial (8), Heart Protection Study 2-Treatment of HDL to Reduce the Incidence of Vascular Events [HPS2-THRIVE] study (176), the Dalcetrapib CVD Outcome Study [DAL-OUTCOMES] (9)), despite significant HDL-C increases. In addition, data from Mendelian randomization studies have shown that common variants that raise HDL-C levels are not associated with a proportionally lower CVD risk.

Simply increasing the amount of circulating HDLcholesterol does not reduce the risk of coronary heart disease (CHD) events, CHD deaths, or total deaths.(177) Heinecke (178) has noted that HDL-cholesterol does not define the proteins associated with HDL and suggests that the HDL proteome is a marker, and perhaps a mediator, of CHD. Zheng et al. (179) reported that ApoA-I, the major protein in HDL, is a selective target for myeloperoxidasecatalyzed oxidation, which results in impairment of the ability of HDL to promote cholesterol efflux. Singh et al. (170) suggested that HDL could be a therapeutic target by modifying its lipid and protein cargo to improve its antiinflammatory properties.

Although it may be premature to suggest at this time, the noncholesterol cargo of HDL may ultimately 
be more closely linked to its beneficial anti-atherogenic properties and may confer many of HDL's benefits outside of CVD. In support of this theory, HDL particle number has recently been found to be a better indicator of CVD risk than HDL-C levels.(180) Although this may be due to the increased ability of more HDL particles for removing excess cholesterol, increasing HDL particle numbers may also affect other functions of HDL and its ability to transport other cargo. Therapeutic strategies to increase HDL particle number may turn out to be better in reducing cardiovascular events than simply increasing HDL-C. One method that has been reported to modify the lipid and protein cargo of HDL involves treatment with apolipoprotein mimetic peptides. (181)

\section{Conclusion}

There has been a recent move toward the view that an accurate assessment of HDL function is likely to provide a more informative assessment of cardiovascular risk than simply measuring HDL-C levels. This has led to considerable progress in recent years in understanding known and identifying new cardioprotective functions of HDLs. There is also a growing awareness that simply measuring HDL-C levels may be less informative than a direct assessment of specific HDL functions. To complicate matters even further, it is also possible that at least some of the known functions of HDL may be specific to particular subsets of HDL particles.

Perhaps it is time for us to change the way we look at HDL and move from a cholesterol-based to a particlebased world. This requires considerable ongoing validation and testing in the clinical trial setting; however, by doing this, we may ultimately get one step closer to a setting in which functional HDL takes center stage. It may be time to rethink the HDL-C hypothesis, not necessarily to replace it, but to expand the role of HDL beyond that of cholesterol to incorporate some of the recent findings on the importance of the other cargo of HDL in CVD.

\section{References}

1. Sharrett AR, Ballantyne CM, Coady SA, Heiss G, Sorlie PD, Catellier $\mathrm{D}$, et al. Coronary heart disease prediction from lipoprotein cholesterol levels, triglycerides, lipoprotein(a), apolipoproteins A-I and B, and HDL density subfractions: the atherosclerosis risk in communities (aric) study. Circulation. 2001; 104: 1108-13.

2. Gordon T, Castelli WP, Hjortland MC, Kannel WB, Dawber TR. High density lipoprotein as a protective factor against coronary heart disease. The Framingham Study. Am J Med. 1977; 62: 707-14.
3. Gordon DJ, Probstfield JL, Garrison RJ, Neaton JD, Castelli WP, Knoke JD, et al. High-density lipoprotein cholesterol and cardiovascular disease. Four prospective American studies. Circulation. 1989; 79: 8-15.

4. Emerging Risk Factors Collaboration, Di Angelantonio E, Sarwar N, Perry P, Kaptoge S, Ray KK, et al. Major lipids, apolipoproteins, and risk of vascular disease. JAMA. 2009; 302: 1993-2000.

5. Barter P, Gotto AM, LaRosa JC, Maroni J, Szarek M, Grundy SM, et al. Treating to New Targets Investigators. HDL cholesterol, very low levels of LDL cholesterol, and cardiovascular events. N Engl J Med. 2007; 357: 1301-10.

6. Vickers KC, Remaley AT. HDL and cholesterol: life after the divorce? J Lipid Res. 2014; 55: 4-12.

7. Barter PJ, Caulfield M, Eriksson M, Grundy SM, Kastelein JJ, Komajda M, et al. Effects of torcetrapib in patients at high risk for coronary events. N Engl J Med. 2007; 357: 2109-22 .

8. AIM-HIGH Investigators, Boden WE, Probstfield JL, Anderson T, Chaitman BR, Desvignes-Nickens $\mathrm{P}$, et al. Niacin in patients with low HDL cholesterol levels receiving intensive statin therapy. N Engl J Med. 2011; 365: 2255-67 .

9. Schwartz GG, Olsson AG, Abt M, Ballantyne CM, Barter PJ, Brumm $\mathrm{J}$, et al. Effects of dalcetrapib in patients with a recent acute coronary syndrome. N Engl J Med. 2012; 367: 2089-99 .

10. Rye KA, Barter PJ. Cardioprotective functions of HDLs. J Lipid Res. 2014; 55: 168-79.

11. Luscher TF, Landmesser U, von Eckardstein A, Fogelman AM. HighDensity Lipoprotein. Vascular protective effects, dysfunction, and potential as therapeutic target. Circ Res. 2014; 114: 171-82.

12. ACCORD Study Group, Ginsberg HN, Elam MB, Lovato LC, Crouse JR 3rd, Leiter LA, et al. Effects of combination lipid therapy in type 2 diabetes mellitus. N Engl J Med. 2010;362:1563-74.

13. Cheung MC, Zhao XQ, Chait A, Albers JJ, Brown BG. Antioxidant Supplements Block the Response of HDL to Simvastatin-Niacin Therapy in Patients With Coronary Artery Disease and Low HDL. Arterioscler Thromb Vasc Biol. 2001; 8: 1320-6.

14. Voight BF, Peloso GM, Orho-Melander M, Frikke-Schmidt R, Barbalic M, Jensen MK, et al. Plasma HDL cholesterol and risk of myocardial infarction: a mendelian randomisation study. Lancet. 2012; 380: 572-80.

15. Varbo A, Benn M, Tybjærg-Hansen A, Jørgensen AB, Frikke-Schmidt R, Nordestgaard BG. Remnant cholesterol as a causal risk factor for ischemic heart disease. J Am Coll Cardiol. 2013; 61: 427-36.

16. Duffy D, Rader DJ. Emerging therapies targeting high-density lipoprotein metabolism and reverse cholesterol transport. Circulation. 2006; 113: 1140-50.

17. Barter PJ, Nicholls S, Rye KA, Anantharamaiah GM, Navab M, Fogelman AM. Antiinflammatory properties of HDL. Circ Res. 2004; 95: 764-72.

18. Cockerill GW, Rye KA, Gamble JR, Vadas MA, Barter PJ. Highdensity lipoproteins inhibit cytokine-induced expression of endothelial cell adhesion molecules. Arterioscler Thromb Vasc Biol. 1995; 15: 1987-94 .

19. Mineo C, Deguchi H, Griffin JH, Shaul PW. Endothelial and antithrombotic actions of HDL. Circ. Res. 2006; 98: 1352-64 .

20. Bisoendial RJ, Hovingh GK, Levels JH, Lerch PG, Andresen I, Hayden MR, et al. Restoration of endothelial function by increasing high-density lipoprotein in subjects with isolated low high-density lipoprotein. Circulation. 2003; 107: 2944-8 .

21. Seetharam D, Mineo C, Gormley AK, Gibson LL, Vongpatanasin W, Chambliss KL, et al. High-density lipoprotein promotes endothelial cell migration and reendothelialization via scavenger receptor-B type I. Circ Res. 2006; 98: 63-72 .

22. Tso C, Martinic G, Fan WH, Rogers C, Rye KA, Barter PJ. Highdensity lipoproteins enhance progenitor mediated endothelium 
repair in mice. Arterioscler Thromb Vasc Biol. 2006; 26: 1144-9.

23. Sumi M, Sata M, Miura S, Rye KA, Toya N, Kanaoka Y, et al. Reconstituted high-density lipoprotein stimulates differentiation of endothelial progenitor cells and enhances ischemia-induced angiogenesis. Arterioscler Thromb Vasc Biol. 2007; 27: 813-8.

24. Yvan-Charvet L, Pagler T, Gautier EL, Avagyan S, Siry RL, Han $\mathrm{S}$, et al. ATP-binding cassette transporters and HDL suppress hematopoietic stem cell proliferation. Science. 2010; 328: 1689-93.

25. Drew BG, Duffy SJ, Formosa MF, Natoli AK, Henstridge DC, Penfold SA, et al. High-density lipoprotein modulates glucose metabolism in patients with type 2 diabetes mellitus. Circulation. 2009; 119: 2103-11.

26. Drew BG, Rye KA, Duffy SJ, Barter P, Kingwell BA. The emerging role of HDL in glucose metabolism. Nat Rev Endocrinol. 2012; 8: 237-45.

27. Nicholls SJ, Puri R. Is it time for HDL to change its tune? Circulation. 2013; 128: 1175-6.

28. Feig JE, Hewing B, Smith JD, Hazen S, Fisher EA. High-density lipoprotein and atheroschlerosis regression. Circ Res. 2014; 114: 205-13.

29. Rader DJ, Tall AR. Is it time to revise the HDL cholesterol hypothesis? Nat Med. 2012; 19: 1344-6.

30. Oldoni F, Sinke RJ, Kuinvenhoven JA. Mendelian disorders of highdensity lipoprotein metabolism. Circ Res. 2014; 114: 124-42.

31. Mulya A, Seo J, Brown AL, Gebre AK, Boudyguina E, Shelness GS, et al. Apolipoprotein $\mathrm{M}$ expression increases the size of nascent pre beta HDL formed by ATP binding cassette transporter A1. J Lipid Res. 2010; 51: 514-24.

32. Rye KA, Clay MA, Barter PJ. Remodelling of high density lipoproteins by plasma factors. Atherosclerosis. 1999; 145: 227-38.

33. Florentin M, Liberopoulos EN, Wierzbicki AS, Mikhailidis DP. Multiple actions of high-density lipoprotein. Curr Opin Cardiol. 2008; $23: 370-8$.

34. Lusa S, Jauhiainen M, Metso J, Somerharju P, Ehnholm C. The mechanism of human plasma phospholipid transfer protein-induced enlargement of high-density lipoprotein particles: evidence for particle fusion. Biochem J. 1996; 313 (Pt 1): 275-82.

35. Valle D, Beaudet AL, Vogelstein B, Kinzler KW, Antonarakis SE, Ballabio A, et al. The Online Metabolic and Molecular Bases of Inherited Diseases (OMMBID). In: Brunzell JD, Deeb SS, editors. Familial Lipoprotein Lipase Deficiency, Apo C-II Deficiency, and Hepatic Lipase Deficiency. New York, NY: McGraw-Hill; 2011 p.40. doi: 10.1036/ommbid. 145

36. Murakami M, Kudo I. New phospholipase A(2) isozymes with a potential role in atherosclerosis. Curr Opin Lipidol. 2003; 14: 4316.

37. Magill P, Rao SN, Miller NE, Nicoll A, Brunzell J, St Hilaire J, et $a l$. Relationships between the metabolism of high-density and very low-density lipoproteins in man: studies of apolipoprotein kinetics and adipose tissue lipoprotein lipase activity. Eur J Clin Invest. 1982; 12: 113-20.

38. Lookene A, Beckstead JA, Nilsson S, Olivecrona G, Ryan RO. Apolipoprotein A-V-heparin interactions: implications for plasma lipoprotein metabolism. J Biol Chem. 2005; 280: 25383-7.

39. Nilsson SK, Lookene A, Beckstead JA, Gliemann J, Ryan RO, Olivecrona G. Apolipoprotein A-V interaction with members of the low density lipoprotein receptor gene family. Biochemistry. 2007; 46: 3896-904.

40. Pollin TI, Damcott CM, Shen H, Ott SH, Shelton J, Horenstein RB, et al. A null mutation in human APOC3 confers a favorable plasma lipid profile and apparent cardioprotection. Science. 2008; 322: 1702-5.

41. Mineo C, Shaul PW. Functions of scavenger receptor class B, type I in atherosclerosis. Curr Opin Lipidol. 2012; 23: 487-93.
42. Camont L, Chapman MJ, Kontush A. Biological activities of HDL subpopulations and their relevance to cardiovascular disease. Trends Mol Med. 2011; 17: 594-603.

43. Balazs Z, Panzenboeck U, Hammer A, Sovic A, Quehenberger O, Malle E, et al. Uptake and transport of high-density lipoprotein (HDL) and HDL-associated alpha-tocopherol by an in vitro bloodbrain barrier model. J Neurochem. 2004; 89: 939-50.

44. Sunesen VH, Weber C, Hølmer G. Lipophilic antioxidants and polyunsaturated fatty acids in lipoprotein classes: distribution and interaction. Eur J Clin Nutr. 2001; 55: 115-23.

45. Behrens WA, Thompson JN, Madère R. Distribution of alphatocopherol in human plasma lipoproteins. Am J Clin Nutr. 1982; 35: 691-6.

46. Traber MG, Diamond SR, Lane JC, Brody RI, Kayden HJ. betaCarotene transport in human lipoproteins. Comparisons with a-tocopherol. Lipids. 1994; 29: 665-9.

47. Akanuma S, Yamamoto A, Okayasu S, Tachikawa M, Hosoya K. High-density lipoprotein-associated alpha-tocopherol uptake by human retinal pigment epithelial cells (ARPE-19 cells): the irrelevance of scavenger receptor class B, type I. Biol Pharm Bull. 2009; 32: 1131-4.

48. Tachikawa M, Okayasu S, Hosoya K. Functional involvement of scavenger receptor class B, type I, in the uptake of alpha-tocopherol using cultured rat retinal capillary endothelial cells. Mol Vis. 2007; 13: 2041-7.

49. Vaisar T, Pennathur S, Green PS, Gharib SA, Hoofnagle AN, Cheung $\mathrm{MC}$, et al. Shotgun proteomics implicates protease inhibition and complement activation in the antiinflammatory properties of HDL. J Clin Invest. 2007; 117: 746-56.

50. Alwaili K, Bailey D, Awan Z, Bailey SD, Ruel I, Hafiane A, et $a l$. The HDL proteome in acute coronary syndromes shifts to an inflammatory profile. Biochim Biophys Acta. 2012; 1821: 405-15.

51. Wehmeier KR, Mazza A, Hachem S, Ligaray K, Mooradian AD, Wong NC, et al. Differential regulation of apolipoprotein A-I gene expression by vitamin D receptor modulators. Biochim Biophys Acta. 2008; 1780: 264-73 .

52. Jaimungal S, Wehmeier K, Mooradian AD, Haas MJ. The emerging evidence for vitamin D-mediated regulation of apolipoprotein A-I synthesis. Nutr Res. 2011; 31: 805-12 .

53. Krinsky NI, Mayne ST, Sies H. Carotenoids in Health and Disease. Boca Raton: CRC Press; 2004.

54. Shaish A, Daugherty A, O'Sullivan F, Schonfeld G, Heinecke JW. Beta-carotene inhibits atherosclerosis in hypercholesterolemic rabbits. J Clin Invest. 1995; 96: 2075-82.

55. Karlsson J, Diamant B, Theorell H, Folkers K. Ubiquinone and alpha-tocopherol in plasma: means of translocation or depot. Clin Investig. 1993; 71: S84-91.

56. Kontush A, Lhomme M, Chapman MJ. Unraveling the complexities of HDL lipidome. J Lipid Res. 2013; 54: 2950-63.

57. Tselepis AD, John Chapman M. Inflammation, bioactive lipids and atherosclerosis: potential roles of a lipoprotein-associated phospholipase A2, platelet activating factor-acetylhydrolase. Atheroscler. 2002; Suppl. 3: 57-68.

58. Bradamante S, Barenghi L, Giudici GA, Vergani C. Free radicals promote modifi cations in plasma high-density lipoprotein: nuclear magnetic resonance analysis. Free Radic Biol Med. 1992; 12: 193 203 .

59. Marchesini N, Luberto C, Hannun YA. Biochemical properties of mammalian neutral sphingomyelinase 2 and its role in sphingolipid metabolism. J Biol Chem. 2003; 278: 13775-83.

60. Nofer JR, Levkau B, Wolinska I, Junker R, Fobker M, von Eckardstein $\mathrm{A}$, et al. Suppression of endothelial cell apoptosis by high density lipoproteins (HDL) and HDL-associated lysosphingolipids. J Biol Chem. 2001; 276: 34480-5. 
61. Argraves KM, Argraves WS. HDL serves as a S1P signaling platform mediating a multitude of cardiovascular effects. J Lipid Res. 2007; 48: 2325-33.

62. Sattler K, Levkau B. Sphingosine-1-phosphate as a mediator of highdensity lipoprotein effects in cardiovascular protection. Cardiovasc Res. 2009; 82: 201-11.

63. Smith JD. Dysfunctional HDL as a diagnostic and therapeutic target. Arterioscler Thromb Vasc Biol. 2010; 30: 151-5.

64. Soran H, Hama S, Yadav R, Durrington PN. HDL functionality. Curr Opin Lipidol. 2012; 23: 353-66.

65. Egom EE, Mamas MA, Soran H. HDL quality or cholesterol cargo: what really matters-spotlight on sphingosine-1-phosphate-rich HDL. Curr Opin Lipidol. 2013; 24: 351-6.

66. Shah AS, Tan L, Long JL, Davidson WS. Proteomic diversity of high density lipoproteins: our emerging understanding of its importance in lipid transport and beyond. J Lipid Res. 2013; 54: 2575-85.

67. Vickers KC, Palmisano BT, Shoucri BM, Shamburek RD, Remaley AT. MicroRNAs are transported in plasma and delivered to recipient cells by high-density lipoproteins. Nat Cell Biol. 2011; 13: 423-33 .

68. Kontush A, Chapman MJ. Functionally defective HDL: a new therapeutic target at the crossroads of dyslipidemia, inflammation and atherosclerosis. Pharmacol Rev. 2006; 3: 342-74.

69. Kontush A, Chapman MJ. Antiatherogenic small, dense HDL guardian angel of the arterial wall? Nat Clin Pract Cardiovasc Med. 2006; 3: 144-53.

70. Jessup W, Gelissen IC, Gaus K, Kritharides L. Roles of ATP binding cassette transporters $\mathrm{A} 1$ and $\mathrm{G} 1$, scavenger receptor BI and membrane lipid domains in cholesterol export from macrophages. Curr Opin Lipidol. 2006; 17: 247-57

71. Oram JF, Lawn RM, Garvin MR, Wade DP. ABCA1 is the cAMPinducible apolipoprotein receptor that mediates cholesterol secretion from macrophages. J Biol Chem. 2000; 275: 34508-11 .

72. Santamarina-Fojo S, Peterson K, Knapper C, Qiu Y, Freeman L, Cheng JF, et al . Complete genomic sequence of the human ABCA1 gene: analysis of the human and mouse ATP-binding cassette A promoter. Proc Natl Acad Sci USA. 2000; 97: 7987-92 .

73. Wang N, Lan D, Chen W, Matsuura F, Tall AR. ATP-binding cassette transporters G1 and G4 mediate cellular cholesterol efflux to highdensity lipoproteins. Proc Natl Acad Sci USA. 2004; 101: 9774-79.

74. Nakamura K, Kennedy MA, Baldán A, Bojanic DD, Lyons K, Edwards PA. Expression and regulation of multiple murine ATPbinding cassette transporter G1 mRNAs/isoforms that stimulate cellular cholesterol efflux to high density lipoprotein. J Biol Chem. 2004; 279: 45980-9.

75. Yancey PG, Bortnick AE, Kellner-Weibel G, de la Llera-Moya M, Phillips MC, Rothblat GH. Importance of different pathways of cellular cholesterol efflux. Arterioscler Thromb Vasc Biol. 2003; 23: 712-9

76. Ji Y, Jian B, Wang N, Sun Y, Moya ML, Phillips MC, et al. Scavenger receptor BI promotes high density lipoprotein-mediated cellular cholesterol efflux. J Biol Chem. 1997; 272: 20982-5

77. Ramírez CM, Rotllan N, Vlassov AV, Dávalos A, Li M, Goedeke L, et al. Control of cholesterol metabolism and plasma HDL levels by miRNA-144. Circ Res. 2013; 112: 1592-601.

78. Moore KJ. microRNAs: small regulators with a big impact on lipid metabolism. J Lipid Res. 2013; 54: 1159-60.

79. Tall AR, Yvan-Charvet L, Westerterp M, Murphy AJ. Cholesterol efflux: a novel regulator of myelopoiesis and atherogenesis. Arterioscler Thromb Vasc Biol. 2012; 32: 2547-52.

80. Murphy AJ, Bijl N, Yvan-Charvet L, Welch CB, Bhagwat N, Reheman A, et al. Cholesterol efflux in megakaryocyte progenitors suppresses platelet production and thrombocytosis. Nat Med. 2013; 19: 586-94.

81. Westerterp M, Murphy AJ, Wang M, Pagler TA, Vengrenyuk Y,
Kappus MS, et al. Deficiency of abca1 and abcg1 in macrophages increases inflammation and accelerates atherosclerosis in mice. Circ Res. 2013; 112: 1456-5.

82. Sorci-Thomas MG, Thomas MJ. High density lipoprotein biogenesis, cholesterol efflux, and immune cell function. Arterioscler Thromb Vasc Biol. 2012; 32: 2561-5.

83. Terasaka N, Westerterp M, Koetsveld J, Fernández-Hernando C, Yvan- Charvet L, Wang N, et al. ATP-binding cassette transporter G1 and high-density lipoprotein promote endothelial NO synthesis through a decrease in the interaction of caveolin-1 and endothelial NO synthase. Arterioscler Thromb Vasc Biol. 2010; 30: 2219-25.

84. Kruit JK, Wijesekara N, Westwell-Roper C, Vanmierlo T, de Haan $\mathrm{W}$, Bhattacharjee A, et al. Loss of both ABCA1 and ABCG1 results in increased disturbances in islet sterol homeostasis, inflammation, and impaired $\beta$-cell function. Diabetes. 2012; 61: 659-64.

85. Yancey PG, de la Llera-Moya M, Swarnakar S, Monzo P, Klein SM, Connelly MA, et al. High density lipoprotein phospholipid composition is a major determinant of the bi-directional flux and net movement of cellular free cholesterol mediated by scavenger receptor BI. J Biol Chem. 2000; 275: 36596-604.

86. Sankaranarayanan S, Oram JF, Asztalos BF, Vaughan AM, Lund-Katz $\mathrm{S}$, Adorni MP, et al. Effects of acceptor composition and mechanism of ABCG1-mediated cellular free cholesterol efflux. J Lipid Res. 2009; 50: 275-84.

87. Navab M, Imes SS, Hama SY, Hough GP, Ross LA, Bork RW, et al. Monocyte transmigration induced by modification of low density lipoprotein in cocultures of human aortic wall cells is due to induction of monocyte chemotactic protein 1 synthesis and is abolished by high density lipoprotein. J Clin Invest. 1991; 88: 203946.

88. Mackness M, Durrington PN, Mackness B. The role of paraoxonase 1 activity in cardiovascular disease: potential for therapeutic intervention. Am J Cardiovasc Drugs. 2004; 4: 211-7.

89. Garner B, Witting PK, Waldeck AR, Christison JK, Raftery M, Stocker R. Oxidation of high density lipoproteins. I. Formation of methionine sulfoxide in apolipoproteins AI and AII is an early event that accompanies lipid peroxidation and can be enhanced by alphatocopherol. J Biol Chem. 1998; 273: 6080-7.

90. Wong WM, Gerry AB, Putt W, Roberts JL, Weinberg RB, Humphries $\mathrm{SE}$, et al. Common variants of apolipoprotein A-IV differ in their ability to inhibit low density lipoprotein oxidation. Atherosclerosis. 2007; 192: 266-74.

91. Ostos MA, Conconi M, Vergnes L, Baroukh N, Ribalta J, Girona $\mathrm{J}$, et al. Antioxidative and antiatherosclerotic effects of human apolipoprotein A-IV in apolipoprotein E-deficient mice. Arterioscler Thromb Vasc Biol. 2001; 21: 1023-8 .

92. Tarnus E, Wassef H, Carmel JF, Rondeau P, Roche M, Davignon $\mathrm{J}$, et al. Apolipoprotein E limits oxidative stress-induced cell dysfunctions in human adipocytes. FEBS Lett. 2009; 583: 2042-8.

93. Zerrad-Saadi A, Therond P, Chantepie S, Couturier M, Rye KA, Chapman MJ, et al. HDL3-mediated inactivation of LDLassociated phospholipid hydroperoxides is determined by the redox status of apolipoprotein A-I and HDL particle surface lipid rigidity: relevance to inflammation and atherogenesis. Arterioscler Thromb Vasc Biol. 2009; 29: 2169-75 .

94. Baker PW, Rye KA, Gamble JR, Vadas MA, Barter PJ. Phospholipid composition of reconstituted high density lipoproteins influences their ability to inhibit endothelial cell adhesion molecule expression. J Lipid Res. 2000; 41: 1261-7.

95. Ashby DT, Rye KA, Clay MA, Vadas MA, Gamble JR, Barter PJ. Barter Factors infl uencing the ability of HDL to inhibit expression of vascular cell adhesion molecule-1 in endothelial cells. Arterioscler Thromb Vasc Biol. 1998; 18: 1450-5 . 
96. McGrath KC, Li XH, Puranik R, Liong EC, Tan JT, Dy VM, et al. Role of 3beta-hydroxysteroid-delta 24 reductase in mediating antiinflammatory effects of high-density lipoproteins in endothelial cells. Arterioscler Thromb Vasc Biol. 2009; 29: 877-82 .

97. Wu BJ, Chen K, Shrestha S, Ong KL, Barter PJ, Rye KA. Highdensity lipoproteins inhibit vascular endothelial inflammation by increasing 3beta-hydroxysteroid-Delta24 reductase expression and inducing heme oxygenase-1. Circ Res. 2013; 112: 278-88 .

98. Rye KA, Bursill CA, Lambert G, Tabet F, Barter PJ. The metabolism and anti-atherogenic properties of HDL. J Lipid Res. 2009; 50: S195-200.

99. Kontush A, Chapman MJ. Antiatherogenic function of HDL particle subpopulations: focus on antioxidative activities. Curr Opin Lipidol. 2010; 21:312-8.

100. Besler C, Heinrich K, Rohrer L, Doerries C, Riwanto M, Shih DM, et al. Mechanisms underlying adverse effects of HDL on eNOSactivating pathways in patients with coronary artery disease. J Clin Invest. 2011; 121: 2693-708.

101. Yuhanna IS, Zhu Y, Cox BE, Hahner LD, Osborne-Lawrence S, Lu $\mathrm{P}$, et al. Highdensity lipoprotein binding to scavenger receptor-BI activates endothelial nitric oxide synthase. Nat Med. 2001; 7: 85357.

102. Drew BG, Fidge NH, Gallon-Beaumier G, Kemp BE, Kingwell BA. High density lipoprotein and apolipoprotein AI increase endothelial NO synthase activity by protein association and multisite phosphorylation. Proc Natl Acad Sci USA. 2004; 101: 6999-7004.

103. Kuvin JT, Rämet ME, Patel AR, Pandian NG, Mendelsohn ME, Karas RH. A novel mechanism for the beneficial vascular effects of high-density lipoprotein cholesterol: enhanced vasorelaxation and increased endothelial nitric oxide synthase expression. Am Heart J. 2002; 144: 165-72.

104. Nofer JR, Assmann G. Atheroprotective effects of highdensity lipoprotein-associated lysosphingolipids. Trends Cardiovasc Med. 2005; $15: 265-71$.

105. Kimura T, Sato K, Malchinkhuu E, Tomura H, Tamama K, Kuwabara A, et al. High-density lipoprotein stimulates endothelial cell migration and survival through sphingosine 1-phosphate and its receptors. Arterioscler Thromb Vasc Biol. 2003; 23: 1283-8.

106. Korporaal SJ, Meurs I, Hauer AD, Hildebrand RB, Hoekstra M, Cate HT, et al . Deletion of the high-density lipoprotein receptor scavenger receptor BI in mice modulates thrombosis susceptibility and indirectly affects platelet function by elevation of plasma free cholesterol. Arterioscler Thromb Vasc Biol. 2011; 31: 34-42 .

107. Ma Y, Ashraf MZ, Podrez EA. Scavenger receptor BI modulates platelet reactivity and thrombosis in dyslipidemia. Blood. 2010; 116: 1932-41.

108. Khera AV, Rader DJ. Future therapeutic directions in reverse cholesterol transport. Curr Atheroscler Rep. 2010; 12: 73-81.

109. Tabet F, Rye KA. High-density lipoproteins, inflammation and oxidative stress. Clin Sci. 2009; 116: 87-98.

110. Speer T, Rohrer L, Blyszczuk P, Shroff R, Kuschnerus K. Abnormal high-densily lipoprotein induces endothelial dysfunction via activation of toll-like receptor-2. Immunity. 2013; 38: 1-15.

111. Mineo C, Shaul PW. Regulation of signal transduction by HDL. J Lipid Res. 2013; 54: 2315-24.

112. Nofer JR, van der Giet M, Tölle M, Wolinska I, von Wnuck Lipinski $\mathrm{K}$, Baba HA, et al. HDL induces NO-dependent vasorelaxation via the lysophospholipid receptor S1P3. J Clin Invest. 2004; 113: 56981.

113. Tall AR, Yvan-Charvet L, Terasaka N, Pagler T, Wang N. HDL, ABC transporters, and cholesterol efflux: implications for the treatment of atherosclerosis. Cell Metab. 2008; 7: 365-75.

114. Rye KA, Barter PJ. Antiinflammatory actions of HDL: a new insight.
Arterioscler Thromb Vasc Biol. 2008; 28: 1890-1.

115. Hessler JR, Robertson AL Jr, Chisolm GM 3rd. LDL-induced cytotoxicity and its inhibition by HDL in human vascular smooth muscle and endothelial cells in culture. Atherosclerosis. 1979; 32: 213-29.

116. van Hinsbergh VW, Scheffer M, Havekes L, Kempen HJ. Role of endothelial cells and their products in the modification of lowdensity lipoproteins. Biochim Biophys Acta. 1986; 878: 49-64.

117. Ohta T, Takata K, Horiuchi S, Morino Y, Matsuda I. Protective effect of lipoproteins containing apoprotein A-I on Cu2+-catalyzed oxidation of human low density lipoprotein. FEBS Lett. 1989; 257: 435-8

118. Parthasarathy S, Barnett J, Fong LG. High-density lipoprotein inhibits the oxidative modification of low-density lipoprotein. Biochim Biophys Acta. 1990; 1044: 275-83

119. Bowry VW, Stanley KK, Stocker R. High density lipoprotein is the major carrier of lipid hydroperoxides in human blood plasma from fasting donors. Proc Natl Acad Sci USA. 1992; 89: 10316-20.

120. Proudfoot JM, Barden AE, Loke WM, Croft KD, Puddey IB, Mori TA. HDL is the major lipoprotein carrier of plasma F2-isoprostanes. J Lipid Res. 2009; 50: 716-22 .

121. Hannson GK. Inflammation, atherosclerosis, and coronary artery disease. N Engl J Med. 2005; 352: 1685-95 .

122. Navab M, Hama SY, Cooke CJ, Anantharamaiah GM, Chaddha M, Jin L, et al. Normal high density lipoprotein inhibits three steps in the formation of mildly oxidized low density lipoprotein: step 1. J. Lipid Res. 2000; 41: 1481-94 .

123. Miyata M, Smith JD. Apolipoprotein E allele-specific antioxidant activity and effects on cytotoxicity by oxidative insults and betaamyloid peptides. Nat Genet. 1996; 14: 55-61

124. Sacre SM, Stannard AK, Owen JS. Apolipoprotein E (apoE) isoforms differentially induce nitric oxide production in endothelial cells. FEBS Lett. 2003; 540: 181-7 .

125. Ophir G, Amariglio N, Jacob-Hirsch J, Elkon R, Rechavi G, Michaelson DM. Apolipoprotein E4 enhances brain inflammation by modulation of the NF-kappaB signaling cascade. Neurobiol Dis. 2005; 20: 709-18.

126. Navab M, Hama-Levy S, Van Lenten BJ, Fonarow GC, Cardinez CJ, Castellani LW, et al. Mildly oxidized LDL induces an increased apolipoprotein J/paraoxonase ratio. J Clin Invest. 1997; 99: 200519.

127. Recalde D, Ostos MA, Badell E, Garcia-Otin AL, Pidoux J, Castro G, et al. Human apolipoprotein A-IV reduces secretion of proinflammatory cytokines and atherosclerotic effects of a chronic infection mimicked by lipopolysaccharide. Arterioscler Thromb Vasc Biol. 2004; 24: 756-61.

128. Vowinkel T, Mori M, Krieglstein CF, Russell J, Saijo F, Bharwani $\mathrm{S}$, et al. Apolipoprotein A-IV inhibits experimental colitis. J Clin Invest. 2004; 114: 260-9.

129. Shih DM, Gu L, Xia YR, Navab M, Li WF, Hama S, et al. Mice lacking serum paraoxonase are susceptible to organophosphate toxicity and atherosclerosis. Nature. 1998; 394: 284-7.

130. Tward A, Xia YR, Wang XP, Shi YS, Park C, Castellani LW, et al. Decreased atherosclerotic lesion formation in human serum paraoxonase transgenic mice. Circulation 2002; 106: 484-90 .

131. Landmesser U, Hornig B, Drexler H. Endothelial function: a critical determinant in atherosclerosis? Circulation 2004; 109: II27-33.

132. Mineo C, Yuhanna IS, Quon MJ, Shaul PW. High density lipoproteininduced endothelial nitric-oxide synthase activation is mediated by Akt and MAP kinases. J Biol Chem. 2003; 278: 9142-9.

133. Dimmeler S, Fleming I, Fisslthaler B, Hermann C, Busse R, Zeiher AM. Activation of nitric oxide synthase in endothelial cells by Aktdependent phosphorylation. Nature. 1999; 399: 601-5.

134. Feig JE, Shamir R, Fisher EA. Atheroprotective effects of HDL: 
beyond reverse cholesterol transport. Curr Drug Targets. 2008; 9: 196-203.

135. Yvan-Charvet L, Welch C, Pagler TA, Ranalletta M, Lamkanfi M, Han $\mathrm{S}$, et al. Increased inflammatory gene expression in $\mathrm{ABC}$ transporter-deficient macrophages: free cholesterol accumulation, increased signaling via toll-like receptors, and neutrophil infiltration of atherosclerotic lesions. Circulation. 2008; 118: 1837-47.

136. Zhu X, Lee JY, Timmins JM, Brown JM, Boudyguina E, Mulya A, et al. Increased cellular free cholesterol in macrophage-specific Abca1 knockout mice enhances pro-inflammatory response of macrophages. J Biol Chem. 2008; 283: 22930-41.

137. Feig JE, Rong JX, Shamir R, Sanson M, Vengrenyuk Y, Liu J, et al. HDL promotes rapid atherosclerosis regression in mice and alters inflammatory properties of plaque monocytederived cells. Proc Natl Acad Sci USA. 2011; 108: 7166-71.

138. Smythies LE, White CR, Maheshwari A, Palgunachari MN, Anantharamaiah GM, et al. Apolipoprotein A-I mimetic 4F alters the function of human monocyte-derived macrophages. Am J Physiol Cell Physiol. 2010; 298: C1538-48.

139. Odegaard JI, Chawla A. Alternative macrophage activation and metabolism. Annu Rev Pathol. 2011; 6: 275-97.

140. Sanson M, Distel E, Fisher EA. HDL induces the expression of the M2 macrophage markers arginase 1 and Fizz-1 in a STAT6dependent process. PLoS One. 2013; 8: e74676. doi: 10.1371/ journal.pone.0074676.

141. Virmani R, Kolodgie FD, Burke AP, Farb A, Schwartz SM. Lessons from sudden coronary death: a comprehensive morphological classification scheme for atherosclerotic lesions. Arterioscler Thromb Vasc Biol. 2000; 20: 1262-75.

142. Libby P. The molecular mechanisms of the thrombotic complications of atherosclerosis. J Intern Med. 2008; 263: 517-27.

143. Burke AP, Farb A, Malcom GT, Liang YH, Smialek J, Virmani R. Coronary risk factors and plaque morphology in men with coronary disease who died suddenly. N Engl J Med. 1997; 336: 1276-82.

144. Dimmeler S, Hermann C, Zeiher AM. Apoptosis of endothelial cells. Contribution to the pathophysiology of atherosclerosis? Eur Cytokine Netw. 1998; 9: 697-98.

145. Sugano M, Tsuchida K, Makino N. High-density lipoproteins protect endothelial cells from tumor necrosis factor-alpha-induced apoptosis. Biochem Biophys Res Commun. 2000; 272: 872-6.

146. Suc I, Escargueil-Blanc I, Troly M, Salvayre R, Nègre-Salvayre A. HDL and ApoA prevent cell death of endothelial cells induced by oxidized LDL. Arterioscler Thromb Vasc Biol. 1997; 17: 2158-66.

147. de Souza JA, Vindis C, Nègre-Salvayre A, Rye KA, Couturier M, Therond P, et al. Small, dense HDL 3 particles attenuate apoptosis in endothelial cells: pivotal role of apolipoprotein A-I. J Cell Mol Med. 2010; 14: 608-20.

148. Holzer M, Birner-Gruenberger R, Stojakovic T, El-Gamal D, Binder $\mathrm{V}$, Wadsack C, et al. Uremia alters HDL composition and function. J Am Soc Nephrol. 2011; 22: 1331-41.

149. Holzer M, Zangger K, El-Gamal D, Binder V, Curcic S, Konya V, et al. Myeloperoxidase-derived chlorinating species induce protein carbamylation through decomposition of thiocyanate and urea: Novel pathways generating dysfunctional high-density lipoprotein. Antioxid Redox Signal. 2012; 17: 1043-52.

150. Tölle M, Huang T, Schuchardt M, Jankowski V, Prüfer N, Jankowski $\mathrm{J}$, et al. High-density lipoprotein loses its anti-inflammatory capacity by accumulation of pro-inflammatory-serum amyloid A. Cardiovasc Res. 2012; 94: 154-62.

151. Weichhart T, Kopecky C, Kubicek M, Haidinger M, Döller D, Katholnig K, et al. Serum amyloid A in uremic HDL promotes inflammation. J Am Soc Nephrol. 2012; 23: 934-47.

152. Charakida M, Besler C, Batuca JR, Sangle S, Marques S, Sousa M, et $a l$. Vascular abnormalities, paraoxonase activity, and dysfunctional
HDL in primary antiphospholipid syndrome. JAMA 2009; 302: 1210-7.

153. McMahon M, Grossman J, FitzGerald J, Dahlin-Lee E, Wallace DJ, Thong BY, et al. Proinflammatory high-density lipoprotein as a biomarker for atherosclerosis in patients with systemic lupus erythematosus and rheumatoid arthritis. Arthritis Rheum. 2006; 54 2541-9.

154. Weihrauch D, Xu H, Shi Y, Wang J, Brien J, Jones DW. Effects of $\mathrm{D}-4 \mathrm{~F}$ on vasodilation, oxidative stress, angiostatin, myocardial inflammation, and angiogenic potential in tight-skin mice. Am J Physiol Heart Circ Physiol. 2007; 93: H1432-41 .

155. de Souza JA, Vindis C, Hansel B, Nègre-Salvayre A, Therond P, Serrano CV Jr, et al. Metabolic syndrome features small, apolipoprotein A-I-poor, triglyceride-rich HDL3 particles with defective anti-apoptotic activity. Atherosclerosis. 2008; 197: 84-94.

156. Sorrentino SA, Besler C, Rohrer L, Meyer M, Heinrich K, Bahlmann $\mathrm{FH}$, et al. Endothelial-vasoprotective effects of high-density lipoprotein are impaired in patients with type 2 diabetes mellitus but are improved after extended-release niacin therapy. Circulation. 2010; 121: 110-22.

157. Perségol L, Vergès B, Foissac M, Gambert $P$, Duvillard L. Inability of HDL from type 2 diabetic patients to counteract the inhibitory effect of oxidised LDL on endothelium-dependent vasorelaxation. Diabetologia. 2006; 49: 1380-6.

158. Riwanto M, Rohrer L, Roschitzki B, Besler C, Mocharla P, Mueller $\mathrm{M}$, et al. Altered activation of endothelial anti- and pro-apoptotic pathways by high-density lipoprotein from patients with coronary artery disease: role of HDL-proteome remodeling. Circulation 2013; 127: 891-904.

159. Ansell BJ, Navab M, Hama S, Kamranpour N, Fonarow G, Hough $\mathrm{G}$, et al. Inflammatory/antiinflammatory properties of high-density lipoprotein distinguish patients from control subjects better than high-density lipoprotein cholesterol levels and are favorably affected by simvastatin treatment. Circulation. 2003; 108: 2751-6.

160. Kalantar-Zadeh K, Kopple JD, Kamranpour N, Fogelman AM, Navab M. HDL-inflammatory index correlates with poor outcome in hemodialysis patients. Kidney Int. 2007; 72: 1149-56.

161. Meiliana A, Wijaya A. HDL: more than cholesterol. Indones Biomed J. 2010; 2: 92-112.

162. Ferretti G, Bacchetti T, Nègre-Salvayre A, Salvayre R, Dousset N, Curatola G. Structural modifications of HDL and functional consequences. Atherosclerosis. 2006; 184: 1-7.

163. Cabana VG, Siegel JN, Sabesin SM. Effects of the acute phase response on the concentration and density distribution of plasma lipids and apolipoproteins. J Lipid Res. 1989; 30: 39-49.

164. Menschikowski M, Hagelgans A, Siegert G. Secretory phospholipase A2 of group IIA: is it an offensive or a defensive player during atherosclerosis and other inflammatory diseases? Prostaglandins Other Lipid Mediat. 2006; 79: 1-33.

165. Coetzee GA, Strachan AF, van der Westhuyzen DR, Hoppe HC, Jeenah MS, de Beer FC. Serum amyloid A-containing human high density lipoprotein 3. Density, size, and apolipoprotein composition. J Biol Chem. 1986; 261: 9644-51.

166. de Beer FC, de Beer MC, van der Westhuyzen DR, Castellani LW, Lusis AJ, Swanson ME, et al. Secretory non-pancreatic phospholipase A2: influence on lipoprotein metabolism. J Lipid Res. 1997; 38: 2232-9.

167. Rye KA, Duong MN. Influence of phospholipid depletion on the size, structure, and remodeling of reconstituted high density lipoproteins. J Lipid Res. 2000; 41: 1640-50.

168. Hedrick CC, Thorpe SR, Fu MX, Harper CM, Yoo J, Kim SM, et al. Glycation impairs high-density lipoprotein function. Diabetologia. 2000; 43: 312-20.

169. Calvo C, Talussot C, Ponsin G, Berthézène F. Non enzymatic 
glycation of apolipoprotein A-I. Effects on its self-association and lipid binding properties. Biochem Biophys Res Commun. 1988; 153: 1060-7.

170. Zheng L, Nukuna B, Brennan ML, Sun M, Goormastic M, Settle M, et al. Apolipoprotein A-I is a selective target for myeloperoxidasecatalyzed oxidation and functional impairment in subjects with cardiovascular disease. J Clin Invest. 2004; 114: 529-41.

171. Fisher EA, Feig JE, Hewing B, Hazen SL, Smith JD. High-density lipoprotein function, dysfunction, and reverse cholesterol transport. Arterioscler Thromb Vasc Biol. 2012; 32: 2813-20.

172. Wu Z, Wagner MA, Zheng L, Parks JS, Shy JM 3rd, Smith JD, et $a l$. The refined structure of nascent HDL reveals a key functional domain for particle maturation and dysfunction. Nat Struct Mol Biol. 2007; 14: 861-8.

173. Shao B, Cavigiolio G, Brot N, Oda MN, Heinecke JW. Methionine oxidation impairs reverse cholesterol transport by apolipoprotein A-I. Proc Natl Acad Sci USA. 2008; 105: 12224-9.

174. Brennan ML, Penn MS, Van Lente F, Nambi V, Shishehbor MH, Aviles RJ, et al. Prognostic value of myeloperoxidase in patients with chest pain. N Engl J Med. 2003; 349: 1595-604.

175. Zhang R, Brennan ML, Fu X, Aviles RJ, Pearce GL, Penn MS, et al. Association between myeloperoxidase levels and risk of coronary artery disease. JAMA. 2001; 286: 2136-42.

176. Merck Newsroom. Merck Announces HPS2-THRIVE Study of TREDAPTIVE $^{\mathrm{TM}}$ (Extended-Release Niacin/Laropiprant) Did Not Achieve Primary Endpoint [webpage on the internet]. Merck; 2012 [cited December 1 2013]. Available from: http://www. mercknewsroom.com/press-release/prescription-medicine-news/ merck-announces-hps2-thrive-study-tredaptive-extended-relea.

177. Briel M, Ferreira-Gonzalez I, You JJ, Karanicolas PJ, Akl EA, Wu $\mathrm{P}$, et al. Association between change in high density lipoprotein cholesterol and cardiovascular disease morbidity and mortality: systematic review and meta-regression analysis. BMJ. 2009; 338: b92. doi: 10.1136/bmj.b92.

178. Heinecke JW. The HDL proteiome: a marker-and perhaps mediator-of coronary artery disease. J Lipid Res. 2009; 50 Suppl: S167-71.

179. Zheng L, Nukuna B, Brennan ML, Sun M, Goormastic M, Settle M, et al. Apolipoprotein A-I is a selective target for myeloperoxidasecatalyzed oxidation and functional impairment in subjects with cardiovascular disease. J Clin Invest. 2004; 114: 529-41.

180. Mackey RH, Greenland P, Goff DC Jr, Lloyd-Jones D, Sibley CT, Mora S. High-density lipoprotein cholesterol and particle concentrations, carotid atherosclerosis, and coronary events: MESA (multi-ethnic study of atherosclerosis). J Am Coll Cardiol. 2012; 60: 508-16.

181. Van Lenten BJ, Navab M, Anantharamaiah GM, Buga GM, Reddy ST, Fogelman AM. Multiple indications for anti-inflammatory apolipoprotein mimetic peptides. Curr Opin Investig Drugs. 2008; 9: $1157-62$. 